\title{
Atmospheric speciated mercury concentrations on an island between China and Korea: sources and transport pathways
}

\author{
Gang-San Lee ${ }^{1}$, Pyung-Rae Kim ${ }^{1}$, Young-Ji Han ${ }^{1}$, Thomas M. Holsen ${ }^{2}$, Yong-Seok Seo ${ }^{3,4}$, and Seung-Muk Yi ${ }^{3}$ \\ ${ }^{1}$ Department of Environmental Science, College of Natural Science, Kangwon National University, 1 Kangwondaehak-gil, \\ Chuncheon, Kangwon-do, 200-701, Republic of Korea \\ ${ }^{2}$ Department of Civil and Environmental Engineering, Clarkson University, 8 Clarkson Ave., Potsdam, NY 13699-5710, USA \\ ${ }^{3}$ Department of Environmental Health, Graduate School of Public Health, Seoul National University, Gwanak-ro, \\ Gwanak-gu, Seoul 151-742, Republic of Korea \\ ${ }^{4}$ Institute of Health and Environment, Seoul National University, 1 Gwanak-ro, Gwanak-gu, Seoul 151-742, \\ Republic of Korea
}

Correspondence to: Young-Ji Han (youngji@kangwon.ac.kr)

Received: 20 October 2015 - Published in Atmos. Chem. Phys. Discuss.: 24 November 2015

Revised: 10 March 2016 - Accepted: 10 March 2016 - Published: 30 March 2016

\begin{abstract}
As a global pollutant, mercury $(\mathrm{Hg})$ is of particular concern in East Asia, where anthropogenic emissions are the largest. In this study, speciated $\mathrm{Hg}$ concentrations were measured on Yongheung Island, the westernmost island in Korea, located between China and the Korean mainland to identify the importance of local and regional $\mathrm{Hg}$ sources. Various tools including correlations with other pollutants, conditional probability function, and back-trajectory-based analysis consistently indicated that Korean sources were important for gaseous oxidized mercury (GOM) whereas, for total gaseous mercury (TGM) and particulate bound mercury (PBM), regional transport was also important. A trajectory cluster based approach, considering both $\mathrm{Hg}$ concentration and the fraction of time each cluster was impacting the site, was developed to quantify the effect of Korean sources and out-of-Korean sources. This analysis suggests that contributions from out-of-Korean sources were similar to Korean sources for TGM whereas Korean sources contributed slightly more to the concentration variations of GOM and PBM compared to out-of-Korean sources. The ratio of GOM / PBM decreased when the site was impacted by regional transport, suggesting that this ratio may be a useful tool for identifying the relative significance of local sources vs. regional transport. The secondary formation of PBM through gas-particle partitioning with GOM was found to be important at low temperatures and high relative humidity.
\end{abstract}

\section{Introduction}

Mercury $(\mathrm{Hg})$ is the only metal that exists as a liquid at standard conditions (US EPA, 1997) which results in it having a significant vapor pressure and presence in the atmosphere. In the atmosphere, $\mathrm{Hg}$ generally does not constitute a direct public health risk at the level of exposure usually found (Driscoll et al., 2007). However, once $\mathrm{Hg}$ is deposited into aquatic systems, it can be transformed into methylmercury $(\mathrm{MeHg})$ which is very toxic and readily bioaccumulates through the food web (Mason et al., 1995). Many studies show that one of the major sources of $\mathrm{MeHg}$ in aquatic and terrestrial system is atmospheric deposition of inorganic Hg (Landis and Keeler, 2002; Mason and Sullivan, 1997). Fish consumption has been considered to be the major exposure pathway of $\mathrm{Hg}$ for humans (Mergler et al., 2007; UNEP, 2013). In Korea, You et al. (2012) showed that MeHg concentrations in blood were affected by fish consumption as well as by gender difference. However, rice consumption was also found to be the predominant pathway of $\mathrm{MeHg}$ exposure for the inhabitants residing in a highly contaminated area of China (Zhang et al., 2010).

Atmospheric mercury exists in three major inorganic forms, including gaseous elemental mercury $\left(\mathrm{GEM}, \mathrm{Hg}^{0}\right)$, gaseous oxidized mercury $\left(\mathrm{GOM}, \mathrm{Hg}^{2+}\right)$ and particulate bound mercury (PBM, $\mathrm{Hg}(\mathrm{p}))$. The sum of the GEM and GOM is often known as total gaseous mercury (TGM). Due 
to its high water solubility and deposition velocity, GOM has short atmospheric residence times ( $\sim$ day) and, consequently, its ambient concentration is mainly affected by local sources. Besides the anthropogenic sources, the free troposphere has been identified as an important GOM source (Huang and Gustin, 2012; Weiss-Penzias et al., 2009; Timonen et al., 2013). In contrast, GEM, which comprises more than 95 percent of the total $\mathrm{Hg}$ in ambient air, can be transported long distances because it is relatively inert and has low water solubility and deposition velocity (Lin and Pehkonen, 1999). The residence time of PBM is dependent on the size of associated particles, but generally, it has been assumed to be a few days (Fang et al., 2012; Zhang et al., 2001). Measurements of GOM and PBM are challenging and uncertain due to their extremely low concentrations and complex chemical reactivity, and because their chemical forms are not actually known (Pirrone et al., 2013). In most studies, GOM and PBM have operational definitions for the mercury species collected by a $\mathrm{KCl}$ coated denuder and by a quartz filter downstream of a $\mathrm{KCl}$ denuder, respectively. It is typically assumed that $\mathrm{GOM}$ comprises $\mathrm{HgCl}_{2}, \mathrm{HgBr}_{2}, \mathrm{HgO}$, $\mathrm{Hg}\left(\mathrm{NO}_{3}\right)_{2}$, and $\mathrm{HgSO}_{4}$. However, the sampling method including the use of a $\mathrm{KCl}$ denuder has been shown to be subject to interferences from ozone, water vapor and possibly other compounds (Lyman et al., 2010; Talbot et al., 2011; Jaffe et al., 2014; Finley et al., 2013; Gustin et al., 2013; Huang et al., 2013; McClure et al., 2014), and it also should be noted that the different $\mathrm{Hg}$ (II) compounds have different collection efficiencies by the $\mathrm{KCl}$ coated denuder (Gustin et al., 2015).

In the atmosphere, $\mathrm{Hg}$ species can be interconverted through various redox reactions. It is known that GOM can be produced by homogeneous and heterogeneous reactions of GEM with $\mathrm{O}_{3}, \mathrm{OH}$, and $\mathrm{Br} / \mathrm{BrO}$ (Hedgecock and Pirrone, 2004; Obrist et al., 2011; Subir et al., 2011), but there is no consensus on which oxidants are most important under which environmental conditions. GEM can also be formed through reduction of GOM predominantly in cloud water (Subir et al., 2011, 2012). GOM can also be converted to PBM through gas-particle partitioning, with the partition coefficient, $K_{\mathrm{p}}$, inversely correlated with temperature and positively correlated with particle surface area (Lyman and Keeler, 2005; Rutter and Schauer, 2007a, b; Liu et al., 2010). Since GEM makes up the bulk of the total $\mathrm{Hg}$ in ambient air its formation through reduction processes of divalent $\mathrm{Hg}$ may not be important. However, the secondary formations of GOM through the oxidation of $\mathrm{Hg}^{0}$ followed by gas-particle partitioning formation of PBM can contribute significantly to their ambient concentrations.

The region of largest anthropogenic $\mathrm{Hg}$ emissions is East and Southeast Asia, contributing $39.7 \%$ of the total global anthropogenic emissions (UNEP, 2013). In Korea, atmospheric Hg emissions have generally decreased since 1990 (Kim et al., 2010). However, Hg levels in Korea are likely to be highly susceptible to Chinese emissions because China alone accounts for about one third of the global total (UNEP, 2013) and Korea is situated just east (and generally downwind) of China. According to the recent studies, $\mathrm{Hg}$ concentrations in the blood of Koreans are more than 4-8 times higher than those found in US and Germany, and approximately $26 \%$ of Koreans have higher blood mercury concentrations than a USA guideline level (http://envhealth.nier.go. $\mathrm{kr}$ ), indicating that there is an urgent need to identify the $\mathrm{Hg}$ sources and pathways controlling $\mathrm{Hg}$ concentrations in Korea.

This study was designed to identify the contribution of various $\mathrm{Hg}$ sources including direct emissions from anthropogenic and natural sources and indirect secondary formation processes to atmospheric $\mathrm{Hg}$ concentrations in Korea. In order to achieve these objectives, $\mathrm{Hg}$ concentrations were measured in the westernmost island in Korea, located in between eastern China and the Korean mainland, so that, depending on wind patterns, the effects of Chinese and Korean $\mathrm{Hg}$ emissions could be evaluated. Previously, our group qualitatively evaluated the impact of local Korean sources and regional Chinese sources on TGM concentrations at the same sampling site (Lee et al., 2014). However, that work was unable to identify the effect of sources on $\mathrm{Hg}$ levels in Korea because only TGM was measured whereas all three $\mathrm{Hg}$ species are needed since they have very different physical and chemical properties. In this study, the importance of sources and pathways was both qualitatively and quantitatively evaluated using all three Hg species' concentrations measured throughout the extended sampling period.

\section{Materials and methods}

\subsection{Site description}

TGM, GOM, and PBM were measured on the roof of a threestory building on Yongheung Island (YI), the westernmost island in Korea (Fig. 1). YI is a small island located about $15-20 \mathrm{~km}$ west from mainland Korea with a population of 5815. The Yongheung coal-fired power plant (YCPP), located approximately $4.5 \mathrm{~km}$ southwest of the sampling site

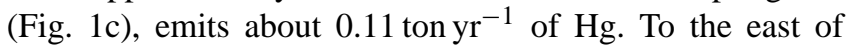
the sampling site, industrial (the Incheon industrial complex shown as light violet color in Fig. 1b and c) and metropoli$\tan$ (Seoul shown as a pink color in Fig. 1b and c) areas are located in mainland Korea, and, in the southern direction, there are three large coal-fired power plants (Fig. 1b). The $\mathrm{Hg}$ emission rate of anthropogenic sources in Korea was estimated to be 8.04 ton $\mathrm{yr}^{-1}$ in 2010, with cement production being the largest source type (AMAP/UNEP, 2013).

\subsection{Sampling and analysis}

From January 2013 to August 2014, three atmospheric mercury species: TGM (GEM + GOM), GOM, and PBM $(\leq 2.5 \mu \mathrm{m})$ were measured during eight intensive sampling 
Table 1. Summarized concentrations of speciated $\mathrm{Hg}$ and other typical pollutants for each sampling period.

\begin{tabular}{lrrrrrrrr}
\hline $\begin{array}{l}\text { Sampling } \\
\text { periods }\end{array}$ & $\begin{array}{r}\mathrm{TGM} \\
\left(\mathrm{ng} \mathrm{m}^{-3}\right)\end{array}$ & $\begin{array}{r}\mathrm{GOM} \\
\left(\mathrm{pg} \mathrm{m}^{-3}\right)\end{array}$ & $\begin{array}{r}\mathrm{PBM} \\
\left(\mathrm{pg} \mathrm{m}^{-3}\right)\end{array}$ & $\begin{array}{r}\mathrm{SO}_{2} \\
(\mathrm{ppb})\end{array}$ & $\begin{array}{r}\mathrm{NO}_{2} \\
(\mathrm{ppb})\end{array}$ & $\begin{array}{r}\mathrm{CO} \\
(\mathrm{ppm})\end{array}$ & $\begin{array}{r}\mathrm{O}_{3} \\
(\mathrm{ppb})\end{array}$ & $\begin{array}{r}\mathrm{PM}_{10} \\
\left(\mu \mathrm{g} \mathrm{m}^{-3}\right)\end{array}$ \\
\hline 1st: 17-23 Jan 2013 & $3.5 \pm 0.8$ & $5.8 \pm 8.8$ & $17.0 \pm 16.5$ & $5.8 \pm 4.2$ & $26.7 \pm 12.4$ & $0.5 \pm 0.2$ & $21.7 \pm 13.5$ & $55.9 \pm 38.5$ \\
2nd: 25 Feb-1 Mar 2013 & $3.7 \pm 0.9$ & $13.2 \pm 14.8$ & $19.5 \pm 19.6$ & $7.3 \pm 3.0$ & $28.8 \pm 19.1$ & $0.7 \pm 0.2$ & $28.3 \pm 14.7$ & $83.6 \pm 28.6$ \\
3rd: 8-13 Apr 2013 & $2.1 \pm 0.4$ & $4.3 \pm 5.6$ & $15.6 \pm 13.8$ & $4.9 \pm 1.7$ & $8.6 \pm 3.3$ & $0.4 \pm 0.1$ & $46.8 \pm 6.0$ & $45.8 \pm 21.4$ \\
4th: 20-25 May 2013 & $2.8 \pm 1.0$ & $4.2 \pm 5.9$ & $6.7 \pm 7.3$ & $5.7 \pm 2.5$ & $17.2 \pm 5.9$ & $0.5 \pm 0.1$ & $36.2 \pm 19.4$ & $51.9 \pm 21.6$ \\
5th: 19-24 Aug 2013 & $2.3 \pm 0.9$ & $3.2 \pm 3.0$ & $5.4 \pm 4.6$ & $4.7 \pm 1.6$ & $10.2 \pm 3.8$ & $0.5 \pm 0.1$ & $40.9 \pm 29.6$ & $34.2 \pm 13.7$ \\
6th: 17-21 Mar 2014 & $2.6 \pm 1.2$ & $12.8 \pm 15.7$ & $7.3 \pm 3.5$ & $7.5 \pm 0.1$ & $32.9 \pm 75.1$ & $0.4 \pm 0.2$ & $39.0 \pm 12.5$ & $66.7 \pm 44.4$ \\
7th: 26-31 May 2014 & $2.8 \pm 0.7$ & $13.5 \pm 9.0$ & $9.8 \pm 12.2$ & $5.8 \pm 2.3$ & $12.4 \pm 5.6$ & $0.5 \pm 0.1$ & $85.5 \pm 23.3$ & $124.5 \pm 44.9$ \\
8th: 19-23 Aug 2014 & $2.4 \pm 1.1$ & $10.7 \pm 3.7$ & $6.3 \pm 3.6$ & $3.4 \pm 1.2$ & $8.7 \pm 6.0$ & $0.4 \pm 0.1$ & $38.7 \pm 16.5$ & $32.0 \pm 22.3$ \\
\hline Average & $2.8 \pm 1.1$ & $8.3 \pm 9.7$ & $10.9 \pm 11.2$ & $5.6 \pm 5.0$ & $18.2 \pm 28.7$ & $0.5 \pm 0.2$ & $42.1 \pm 25.8$ & $61.9 \pm 42.8$ \\
\hline
\end{tabular}

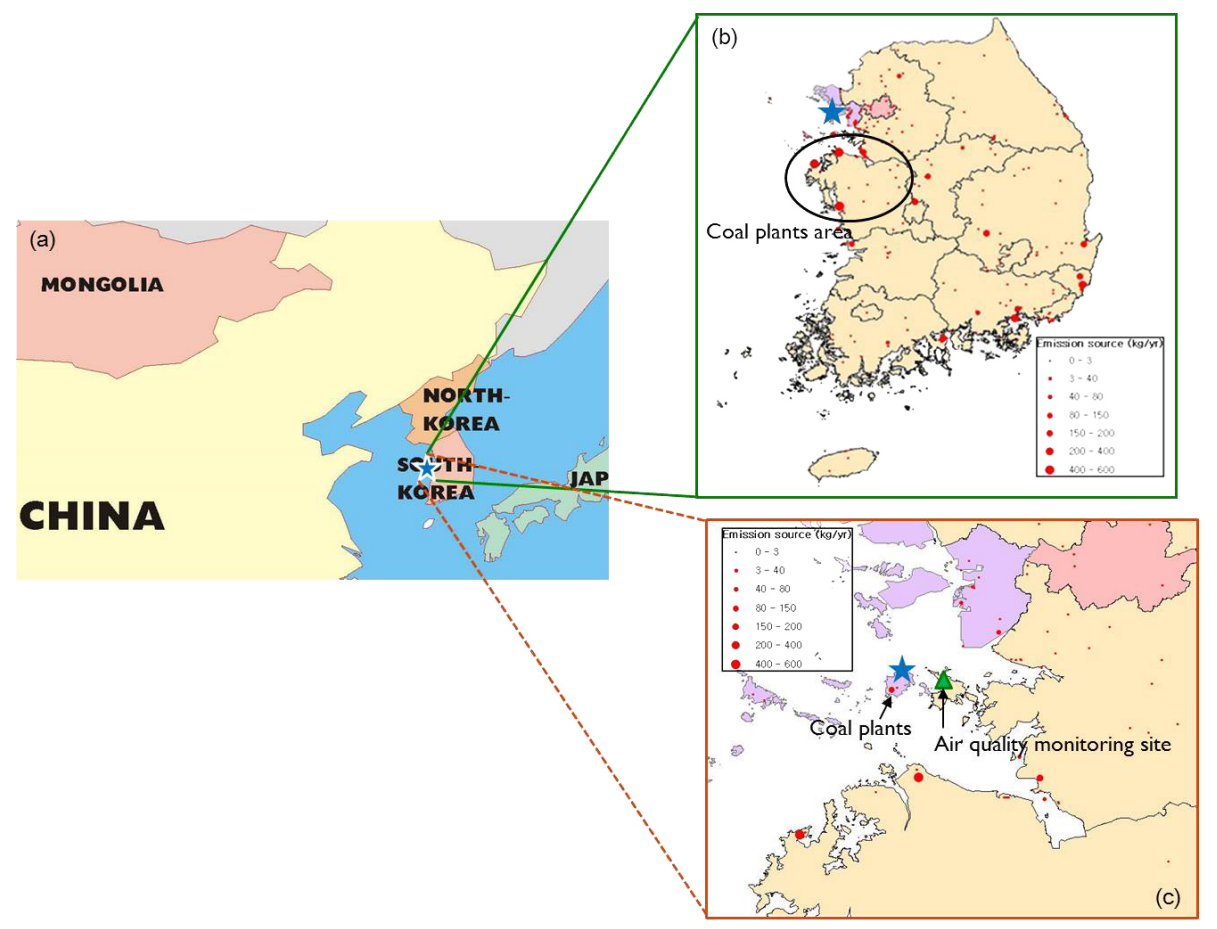

Figure 1. (a) The sampling site in Yongheung Island (the star mark). (b) Anthropogenic mercury emission sources in Korea. Blue star indicates the sampling site, and the green circle indicates the area where major Korean coal-fired power plants are located. (c) The enlarged image of the area near the sampling site.

periods (Table 1). TGM concentrations were measured every 5 min using a mercury vapor analyzer (Tekran 2537B). This instrument contains two gold cartridges which collect and thermally desorb $\mathrm{Hg}$ alternately. Desorbed $\mathrm{Hg}$ is quantified using cold vapor atomic fluorescence spectrometry (CVAFS). Outdoor air at a flow rate of $1.0 \mathrm{~L} \mathrm{~min}^{-1}$ was transported through a $3 \mathrm{~m}$ long heated sampling line $\left(1 / 4^{\prime \prime}\right.$ OD Teflon) into the analyzer. There is a possibility that some GOM may be absorbed in the line upstream of the gold traps although the sampling line and inlet were maintained at $50^{\circ} \mathrm{C}$ to prevent the GOM sorption. However, it is typically assumed that Tekran 2537 can collect and analyze TGM in most of the studies (Temme et al., 2002; Gustin et al., 2013; Han et al., 2014; Zhang et al., 2015). The Tekran 2537B was automatically calibrated daily using an internal permeation source. Manual injections were also used to evaluate these automated calibrations before each sampling campaign using a saturated mercury vapor standard. The relative percent difference between manual injection and automated calibration was $<2 \%$. Five-point manual calibration was also performed by injecting $\mathrm{Hg}$ vapor into the sampling line two times during the study period. The $R^{2}$ ranged from 0.9991 to 0.9997 between mass injected and Tekran reported area, and the average relative percent difference between the mass 
injected and the mass calculated was $5.5 \%$. The method detection limit $\left(0.04 \mathrm{ng} \mathrm{m}^{-3}\right)$ was calculated as three times the standard deviation obtained after injecting $1 \mathrm{pg}$ of the mercury vapor seven times. The recovery rate $(96 \pm 3 \%)$ was obtained by directly injecting $\mathrm{Hg}$ vapor into the sampling line between the sample inlet and the Tekran 2537B in a zero-air stream.

GOM and PBM were collected manually using an annular denuder coated with $\mathrm{KCl}$ followed by a quartz filter, respectively, at a flow rate of $10 \mathrm{~L} \mathrm{~min}^{-1}$. To identify any diurnal variations, all samples were separately collected during the daytime (07:00-19:00) and nighttime (19:00-07:00) except during the 7th sampling period when they were measured every $2 \mathrm{~h}$. The sampling system including an elutriator, an impactor, a $\mathrm{KCl}$-coated denuder and a filter pack was housed in a custom-made sampling box maintained at $45^{\circ} \mathrm{C}$ to prevent hydrolysis of $\mathrm{KCl}$. After sampling, the denuder and quartz filter were thermally desorbed using a tube furnace at 525 and $900{ }^{\circ} \mathrm{C}$, respectively, to convert $\mathrm{Hg}^{2+}$ to $\mathrm{Hg}^{0}$ in a carrier gas of zero air. The heated air was then transported into a Tekran 2537B for quantification. Field blanks for GOM and PBM were collected once for each sampling period, and their average values were $0.23 \pm 0.12$ and $0.25 \pm 0.09 \mathrm{pg} \mathrm{m}^{-3}$, respectively.

The sampling methods used in this study are currently the most accepted methods for the measurement of atmospheric GOM and PBM, however there are many studies reporting that these methods are subject to interferences from ozone, water vapor, and possibly other compounds (Lyman et al., 2010; Talbot et al., 2011; Jaffe et al., 2014; Finley et al., 2013; Gustin et al., 2013; Huang et al., 2013; McClure et al., 2014) although recent side-by-side measurements with two Tekran systems showed good agreement and no impact from added ozone and increasing relative humidity (Edgerton, 2015). Also, it should be noted that the concentrations of PBM measured during $12 \mathrm{~h}$ of sampling time (all sampling periods except in the 7th) may have been biased due to $\mathrm{Hg}$ loss from filters over the long sampling period (Malcolm and Keeler, 2007; Wang et al., 2013); however for model development any loss of PBM is assumed to be the same for each sampling period. Therefore, it should be noted that the GOM and PBM measurements reported in this study may be somewhat biased even though, at present, it is not possible to quantify the magnitude of these uncertainties.

Meteorological data including temperature, wind speed, wind direction, relative humidity, and solar radiation were also measured every $5 \mathrm{~min}$ at the sampling site using a meteorological tower (DAVIS Inc weather station, Vintage Pro $2^{\mathrm{TM}}$ ).

Hourly concentrations of $\mathrm{SO}_{2}, \mathrm{NO}_{2}, \mathrm{CO}, \mathrm{O}_{3}$ and $\mathrm{PM}_{10}$ were obtained from the national air quality (NAQ) monitoring station (http://www.airkorea.or.kr/) located approximately $8 \mathrm{~km}$ east from the sampling site. These concentrations were compared with those measured at another national air quality monitoring station located approximately $24 \mathrm{~km}$ west of the Hg sampling site, and there were no statistical differences between sites ( $p$ value $<0.001$ ), indicating that the spatial distribution of these pollutants was relatively uniform across the area.

\subsection{Backward trajectory and cluster analysis}

Three-day backward trajectories were calculated using the NOAA HYSPLIT 4.7 with GDAS (Global Data Assimilation System) meteorological data which supplies 3-h, global $1^{\circ}$ latitude-longitude data sets of the pressure surface. Hourly 3-day back trajectories were calculated for each hour of sampling, and the arrival heights of both 200 and $500 \mathrm{~m}$ were used to describe the local and the regional transport meteorological pattern. Since GOM and PBM were measured for $12 \mathrm{~h}$ for most time periods, hourly trajectories were matched to the $12 \mathrm{~h}$ averaged GOM and PBM concentration; therefore, in total 12 back trajectories represented one averaged GOM or PBM concentrations. Although there have been many studies using different timescales for measurements of pollutants and for meteorological data (Amato and Hopke, 2012; Galindo et al., 2011; Kim et al., 2007), this mismatch might increase the uncertainty for the trajectory-based approaches.

The backward trajectories were clustered into groups with similar transport patterns using NOAA HYSPLIT 4.7. This method minimizes the intra-cluster differences among trajectories while maximizing the inter-cluster differences. The clustering of trajectories is based on the total spatial variance (TSV) method. TSV is the sum of all the cluster spatial variances (SPVAR) which is the sum of the squared distances between the endpoints of the cluster's component trajectories and the mean of the trajectories in that cluster. In this study, five clusters were chosen based on a large increase in TSV for larger clusters (Fig. S4), as described in Draxler et al. (2014) and Kelly et al. (2012). A more detailed description of the clustering process can be obtained in Draxler et al. (2014).

\subsection{Conditional probability function (CPF)}

The conditional probability that a given concentration from a given wind direction will exceed a predetermined threshold criterion, was calculated using the following equation:

$\mathrm{CPF}_{\Delta \theta}=\frac{m_{\Delta \theta}}{n_{\Delta \theta}}$,

where $m_{\Delta \theta}$ is the number of occurrences from wind sector $\Delta \theta$ where the concentration is higher than a criterion value, and $n_{\Delta \theta}$ is the total number of occurrence from this wind sector. In this study, 16 sectors were used $\left(\Delta \theta=22.5^{\circ}\right)$, and calm winds were excluded from the calculation because of isotropic behavior of the wind vane for such conditions. For TGM, two threshold criteria of the upper 10 and 25 percentile were chosen while only the upper 25 percentile was used for GOM and PBM concentrations due to the smaller number of 
samples. The $1 \mathrm{~h}$ averaged wind direction (WD) data were used for $12 \mathrm{~h}$ averaged GOM and PBM concentrations for most of the periods, so that in total $12 \mathrm{WS}$ and WD were used for one averaged GOM and PBM concentrations to create CPF. It should be noted that there are some unquantifiable uncertainties derived from using different time resolutions between measurements of GOM and PBM and WD data although overall trajectories did not diverge significantly at this sampling site for most sampling periods.

\subsection{Potential source contribution function (PSCF)}

The PSCF model counts each trajectory segment endpoint that terminates within given grid cell. A high PSCF value signifies a potential source location. The PSCF value was calculated as

PSCF value $=\frac{P\left[B_{i j}\right]}{P\left[A_{i j}\right]}=\frac{m_{i j}}{n_{i j}}$,

If $N$ is the total number of trajectory segment endpoints over the study period and if $n$ segment trajectory endpoints fall into the $i j$ th cell, the probability of this event $\left(P\left[A_{i j}\right]\right)$ is calculated by $n_{i j} / N$. If $m_{i j}$ is the number of segment endpoints in the same $i j$ th cell when the concentrations are higher than a criterion value, the probability of this high concentration event, $B_{i j}$, is given by $P\left[B_{i j}\right]=m_{i j} / N$. The criterion value was the top $25 \%$ concentration and the cell size of $0.5^{\circ}$ by $0.5^{\circ}$ was used for tracing sources. To reduce the uncertainty in a grid cell with a small number of endpoints, an arbitrary weight function $W_{i j}$ was applied when the number of the endpoints in a particular cell was less than three times the average number of endpoints $\left(N_{\text {ave }}\right)$ for all cells (Fu et al., 2011; Han et al., 2007; Polissar et al., 2001a, b).

$$
W_{i j}=\left(\begin{array}{lc}
1.0 & N_{i j}>3 N_{\text {ave }} \\
0.70 & 3 N_{\mathrm{ave}}>N_{i j}>1.5 N_{\mathrm{ave}} \\
0.40 & 1.5 N_{\mathrm{ave}}>N_{i j}>N_{\mathrm{ave}} \\
0.20 & N_{\mathrm{ave}}>N_{i j}
\end{array}\right)
$$

In this study, trajectories were hourly calculated.

\section{Results and discussion}

\subsection{General trends of three $\mathrm{Hg}$ species}

To maintain the consistency of the sampling duration, the $12 \mathrm{~h}$ averaged GOM and PBM concentrations were used for the 7th sampling period to identify the general trends of $\mathrm{Hg}$ species. The average TGM, GOM, and PBM concentrations were $2.8 \pm 1.1 \mathrm{ng} \mathrm{m}^{-3}, 8.3 \pm 9.7 \mathrm{pg} \mathrm{m}^{-3}$, and $10.9 \pm 11.2 \mathrm{pg} \mathrm{m}^{-3}$, respectively (Table 1 ). Since the GOM concentration was much lower than TGM the reported TGM concentration can be considered a good approximation of the GEM concentration. TGM varied from 0.1 to $18.8 \mathrm{ng} \mathrm{m}^{-3}$; the highest concentration was observed between 1:35 a.m.

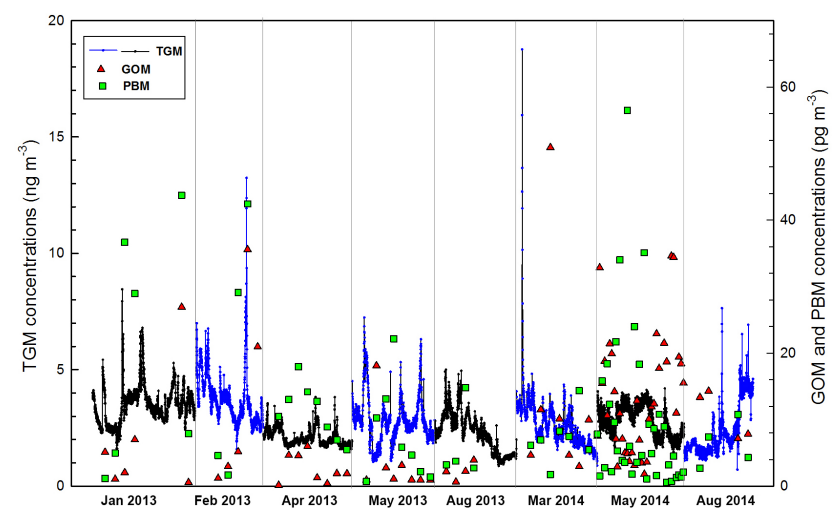

Figure 2. TGM, GOM, and PBM concentrations measured during the eight sampling periods. TGM was measured every $5 \mathrm{~min}$ while GOM and PBM were measured during $12 \mathrm{~h}$ except for the $2 \mathrm{~h}$ measurements during May 2014.

2 a.m. on 18 March 2014 (Fig. 2). GOM and PBM concentrations peaked at $50.9 \mathrm{pg} \mathrm{m}^{-3}$ during the daytime on 19 March 2014 and $43.7 \mathrm{pg} \mathrm{m}^{-3}$ during daytime on 22 January 2013, respectively (Fig. 2). The various $\mathrm{Hg}$ species did not follow similar concentration patterns although PBM was statistically significantly correlated with TGM (Pearson correlation coefficient, $r=0.235, p$ value $=0.03$ ).

When the data were grouped into three categories including the first (April, May 2013, March, May 2014), the second (August 2013, August 2014), and the third (January, February 2013) periods, both TGM (ANOVA/Tukey test, $p$ value $<0.001$ ) and PBM ( $p$ value $=0.024$, KruskaWallis test) had the highest concentrations in the cold period (January, February 2013) while there was no statistical difference in GOM concentrations among different categories $(p$ value $=0.288$, Kruskal-Wallis test) $($ Fig. 3$)$. Observed TGM concentrations were substantially lower than those measured in a suburban and remote site in China and metropolitan areas of Korea (Seoul), but higher than at most North American sites and at a rural site of Korea (Chuncheon) (Table 2). GOM and PBM concentrations were in between those typically found at urban locations and at a rural site in Korea and were much lower than those typically measured in China.

The TGM concentration varied diurnally, generally showing morning maximums (07 a.m.-12:00 a.m.) and minimums during the nighttime. In urban areas, TGM concentrations are typically higher during the nighttime due to a combination of decreased GEM loss by daytime oxidation, increased use of household heating systems and decreased mixing heights at night (Kim et al., 2012; Han et al., 2014). In contrast, daytime peaks have been observed in rural and remote areas, likely due to increased volatilization of $\mathrm{Hg}^{0}$ from natural sources (Choi et al., 2008; Cheng et al., 2014). Overall these results suggest that TGM concentrations at this site are elevated due to the proximity of regional sources and daily variations that 
Table 2. Comparisons of measured $\mathrm{Hg}$ concentrations with those reported in other studies.

\begin{tabular}{|c|c|c|c|c|c|c|c|}
\hline Country & Site & Remarks & Year & $\begin{array}{r}\text { TGM } \\
\left(\mathrm{ng} \mathrm{m}^{-3}\right)\end{array}$ & $\begin{array}{r}\text { GOM } \\
\left(\mathrm{pg} \mathrm{m}^{-3}\right)\end{array}$ & $\begin{array}{r}\mathrm{PBM} \\
\left(\mathrm{pg} \mathrm{m}^{-3}\right)\end{array}$ & Reference \\
\hline \multirow[t]{4}{*}{ Korea } & Seoul & Urban & 2005-2006 & $3.22 \pm 2.10$ & $27.2 \pm 19.3$ & $23.9 \pm 19.6$ & Kim et al. (2009) \\
\hline & Seoul & Urban & 2006-2009 & $3.72 \pm 2.96$ & $11.3 \pm 9.5$ & $13.4 \pm 12.0$ & Han et al. (2014) \\
\hline & Chuncheon & Rural & 2006-2009 & $2.12 \pm 1.47$ & $2.7 \pm 2.7$ & $3.7 \pm 5.7$ & Han et al. (2014) \\
\hline & Yongheung & Island & 2013-2014 & $2.8 \pm 1.1$ & $9.8 \pm 9.9$ & $10.6 \pm 12.0$ & This study \\
\hline \multirow[t]{3}{*}{ China } & Guiyang & Urban & 2009 & $9.7 \pm 10.2$ & $35.7 \pm 43.9$ & $368.0 \pm 676.0$ & Fu et al. (2011) \\
\hline & Xiamen & Suburban & 2012-2013 & 3.5 & 61.05 & 174.41 & Xu et al. (2015) \\
\hline & Mt. Changbai & Remote & 2005-2006 & $3.58 \pm 1.78$ & $65 \pm 84$ & $77 \pm 136$ & Wan et al. $(2009 a, b)$ \\
\hline \multirow[t]{3}{*}{ USA } & Chicago & Urban & 2007 & $2.5 \pm 1.5$ & $17 \pm 87$ & $9 \pm 20$ & Gratz et al. (2013) \\
\hline & Reno, Nevada & Suburban & 2007-2009 & $2.0 \pm 0.7$ & $18 \pm 22$ & $7 \pm 7$ & Lyman and Gustin (2009) \\
\hline & Rochester, NY & Urban & 2008-2009 & 1.49 & 4.08 & 6.57 & Huang et al. (2010) \\
\hline \multirow[t]{2}{*}{ Canada } & Nova Scotia & Urban & 2010-2011 & $1.67 \pm 1.01$ & $2.07 \pm 3.35$ & $2.32 \pm 3.09$ & Cheng et al. (2014) \\
\hline & Ontario & Rural & 2006-2007 & 1.17 & 15.10 & 16.40 & Baya and Van Heyst (2010) \\
\hline
\end{tabular}

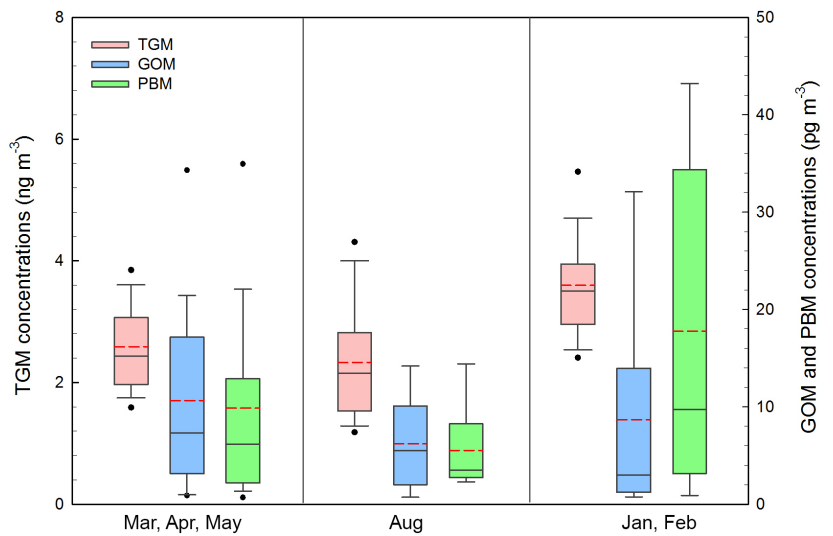

Figure 3. Box-and-whisker plot for the concentrations of TGM, GOM, and PBM during three different periods. The red dash lines indicate the arithmetic mean.

are controlled by natural emissions from the ocean and soil surfaces.

GOM concentrations were highest in spring $\left(10.7 \pm 10.1 \mathrm{pg} \mathrm{m}^{-3}\right)$ and lowest in summer $\left(6.2 \pm 4.9 \mathrm{pg} \mathrm{m}^{-3}\right)$ with statistically insignificant seasonal variation (Fig. 3). The lack of a GOM seasonal variation for could be an indicator of insignificant secondary formation through photochemical oxidation reactions, but it might also be due to the small sample numbers and/or relatively long sampling duration (12 h). PBM concentrations did have statistically significant seasonal variations with the highest average concentration in winter $\left(17.8 \pm 16.7 \mathrm{pg} \mathrm{m}^{-3}\right)$ and the lowest average concentration in summer $\left(5.8 \pm 4.1 \mathrm{pg} \mathrm{m}^{-3}\right)$ (Fig. 3). Higher PBM concentrations in winter were likely caused by increased biomass burning and residential heating, decreased removal from the atmosphere due to the lower precipitation depth, and/or lower temperatures which favor partitioning to the aerosol phase. Previous studies also often observed the highest PBM concentrations in winter (Mao et al., 2012; Amos et al., 2012; Lan et al., 2012).

In Korea emissions of PBM from anthropogenic sources are much smaller then gaseous emissions (the proportion of GEM, GOM, and PBM released are 64.4, 28.8, and 6.8\%) (Kim et al., 2010). The fact that PBM concentrations are similar to GOM even though significantly less PBM is released suggests that a significant portion of atmospheric PBM may be due to secondary formation through gas-particle partitioning. This process is characterized by a partition coefficient, $K_{\mathrm{p}}$, which is inversely correlated with temperature (Rutter and Schauer, 2007a), possibly causing the distinct seasonal variation in PBM concentrations at the sampling site.

The relationship between $K_{\mathrm{p}}$, defined as

$K_{\mathrm{p}}=\frac{\mathrm{PBM} / \mathrm{PM}}{\mathrm{Hg}_{\mathrm{gas}}}$,

where PM represents the particle mass, and $\mathrm{Hg}_{\text {gas }}$ is the concentration of gaseous $\mathrm{Hg}$ and relative humidity (RH) was examined $\left(\mathrm{PM}_{10}\right.$ concentration was used for $\mathrm{PM}$ in Eq. 4 in this study). RH was included because in recent studies $K_{\mathrm{p}}$ was found to increase at high relative humidity in colder seasons (Lyman and Keeler, 2005; Liu et al., 2010). Note that the sampling site was located in a coastal area with generally high RH.

Some previous studies suggested that all gaseous mercury species including $\mathrm{Hg}^{0}$ may deposit on particles (Xiu et al., 2005, 2009); however, others suggested that the gas-particle partitioning of GOM occurred but assumed that the adsorption of $\mathrm{Hg}^{0}$ on particles was negligible due to its high vapor pressure (Amos et al., 2012; Rutter and Schauer, 2007a). Consistent with this hypothesis, we found a statistically significant multiple linear relationship between $K_{\mathrm{p}}$ with temper- 
ature and relative humidity (Fig. 4):

$\log \left(K_{\mathrm{p}}\right)=-2.518-0.036(T)+0.017(\mathrm{RH})$,

where $T$ and $\mathrm{RH}$ indicate atmospheric temperature $\left({ }^{\circ} \mathrm{C}\right)$ and relative humidity $(\%)$, respectively. The multiple linear equation fit the data well $\left(R^{2}=0.29, R=0.54, p\right.$ value $\left.<0.001\right)$, and both variables of temperature and relative humidity were statistically significant $(p$ value $<0.001)$. The partial correlation coefficients were -0.389 for temperature ( $p$ value $<0.001)$ and 0.375 for $\mathrm{RH}(p$ value $=0.001)$. When each of the temperature and the $\mathrm{RH}$ was used as a single independent variable the $\log \left(K_{\mathrm{p}}\right)$ regression equation was still significant with a Pearson correlation coefficient of $-0.42\left(R^{2}=0.18, p\right.$ value $\left.<0.001\right)$ and 0.39 $\left(R^{2}=0.15, p\right.$ value $\left.<0.001\right)$, somewhat lower than that from the multiple regression (Fig. S1 in the Supplement). Amos et al. (2012) found an empirical gas-particle partitioning relationship between $K_{\mathrm{p}}$ and $T$ using the $\mathrm{Hg}$ data obtained from five monitoring sites in the United States and Canada and two laboratory experiments, and the average equation is

$\log \left(1 / K_{\mathrm{p}}\right)=(10 \pm 1)-(2500 \pm 300) / T$,

where $T$ is in Kelvin unit. When a partial linear regression was performed with $T$ in this study a similar equation was derived: $\log \left(1 / K_{\mathrm{p}}\right)=13.5-3362.7 / T$. In Amos et al. (2012), the coefficients, $\beta$ and $y_{0}$, ranged from -1600 to -3300 and 6 to 13 , respectively, and $R^{2}$ ranged from 0.16 to 0.57 in different monitoring sites. Rutter and Schauer (2007a) also determined the relationship between $\log \left(1 / K_{\mathrm{p}}\right)$ for urban aerosols with inverse temperature and found the slope and intercept were $-4250 \pm 480$ and $10 \pm 2$, respectively, with $R^{2}$ of 0.77 . Another study using data sets from 10 AMNet sites located in North America found $R^{2}$ ranged between 0.04 and 0.53 . In summary the values derived in this study fall between those reported by other studies. Somewhat lower $R^{2}$ in this study is probably caused by a smaller number of samples, different composition of aerosol, different GOM species, and/or longer sampling duration.

Han et al. (2014) also found a significant multiple linear relationship between the ratio of PBM / GOM with temperature and relative humidity at a rural site $\left(R^{2}=0.613, \beta\right.$ for $T=-0.774, \beta$ for $\mathrm{RH}=0.33$ ) but not at an urban site. The lower correlation coefficient and the beta values found in this study compared to those from Han et al. (2014) are probably due to the greater impact of primary anthropogenic sources around the sampling site. A large anthropogenic source near the sampling site is likely to weaken the relative contribution of gas-particle partitioning (secondary formation) to the variations of ambient PBM and GOM concentration because both $\mathrm{Hg}$ species can be also strongly affected by the primary source emission. In the study of Amos et al. (2012), the highest $R^{2}$ was shown in Experimental Lakes Area of Canada and Reno, NV where no large anthropogenic sources of $\mathrm{Hg}$ are located.

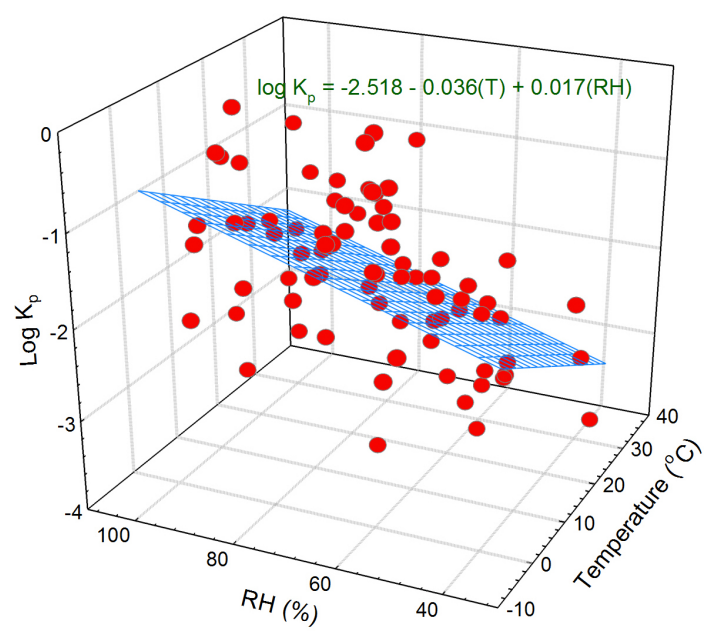

Figure 4. The gas-particle partitioning coefficient, $K_{\mathrm{p}}$, related to atmospheric temperature and relative humidity $(\mathrm{RH})(n=81)$.

In previous researches, GOM concentration measured using $\mathrm{KCl}$ denuder is subject to interferences under the conditions of high ozone and relative humidity (Gustin et al., 2013, 2015; Huang et al., 2013) although it is currently the most accepted method. To evaluate the possible error on interpreting result, $K_{\mathrm{p}}$ was re-calculated with re-calculated GOM concentration using the empirical equation suggested by McClure et al. (2014) $(\mathrm{RH}=0.63 \mathrm{GOM}$ loss $\%+18.1)$. Since McClure et al. (2014) suggested this equation at an RH of 21 to $62 \%$, the GOM concentrations which were collected were re-calculated only when $\mathrm{RH}$ was from 20 to $65 \%$. The multilinear relationship was compared between re-calculated $K_{\mathrm{p}}$ and original $K_{\mathrm{p}}$, and the results were very similar to each other (Fig. S2).

\subsection{Tracing sources of $\mathrm{Hg}$ species}

Correlations between $\mathrm{Hg}$ and other pollutant concentrations are often used to identify sources. For example good correlations with $\mathrm{SO}_{2}$ and $\mathrm{CO}$ typically indicate the impact of coal combustion (Pirrone et al., 1996; Han et al., 2014), and a strong correlation between $\mathrm{Hg}$ and $\mathrm{CO}$ has often been used as an indicator for regional transport because both pollutants have similar sources and do not easily decompose by reaction and undergo deposition during transport (Weiss-Penzias et al., 2003, 2006; Kim et al., 2009); although a few recent studies showed the significant bromine-induced oxidation of GEM in the mid-latitude marine boundary layer as well as in the polar atmosphere (Ariya, 2011; Obrist et al., 2011). A good correlation between $\mathrm{Hg}$ and $\mathrm{NO}_{2}$ suggests the site is being impacted by local sources because the lifetime of $\mathrm{NO}_{2}$ is relatively short compared with that of CO (Seinfeld and Pandis, 2006). In this study TGM concentrations were well correlated with $\mathrm{SO}_{2}, \mathrm{CO}$, and $\mathrm{PM}_{10}$ concentrations but not 
Table 3. Correlation coefficients and $p$ values (in parenthesis) for speciated $\mathrm{Hg}$ with other pollutants for the whole sampling period. Correlation coefficients with an asterisk indicate a statistically significant relationship at $\alpha=0.05$.

\begin{tabular}{lrrrrrrr}
\hline & $\mathrm{TGM}$ & $\mathrm{GOM}$ & $\mathrm{SO}_{2}$ & $\mathrm{NO}_{2}$ & $\mathrm{CO}$ & $\mathrm{O}_{3}$ & $\mathrm{PM}_{10}$ \\
\hline TGM & - & $-0.132(0.233)$ & $0.115^{*}(0.001)$ & $0.063(0.074)$ & $0.571^{*}(<0.001)$ & $-0.055(0.115)$ & $0.401^{* *}(<0.001)$ \\
$\mathrm{GOM}$ & $-0.132(0.233)$ & - & $0.025(0.822)$ & $0.022(0.846)$ & $-0.149(0.180)$ & $0.143(0.197)$ & $0.128(0.248)$ \\
PBM & $0.235^{*}(0.030)$ & $0.021(0.855)$ & $-0.006(0.954)$ & $0.008(0.941)$ & $0.215^{*}(0.048)$ & $0.029(0.794)$ & $0.139(0.206)$ \\
\hline
\end{tabular}
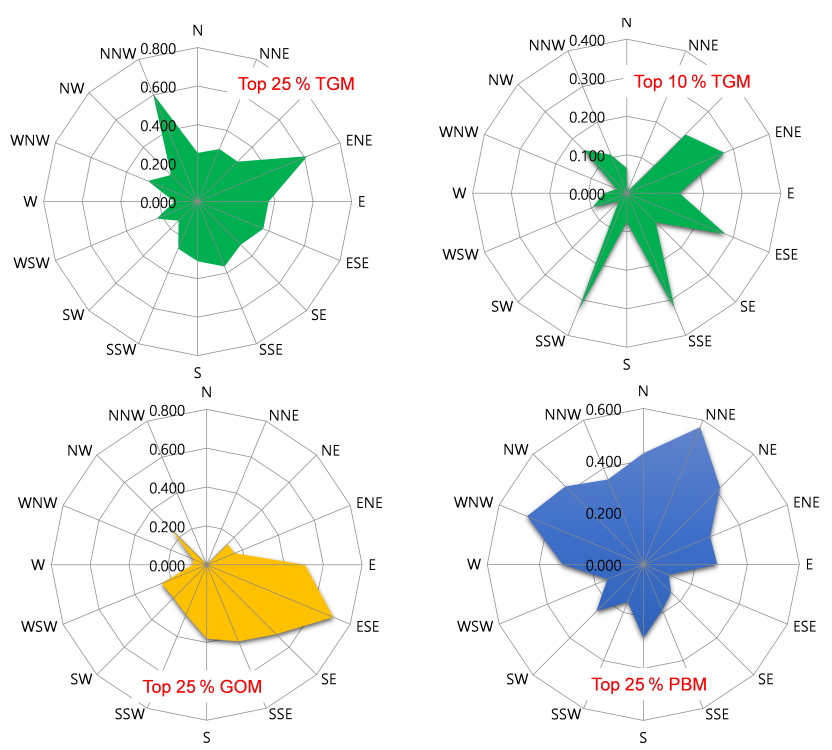

Figure 5. CPF plots for TGM using the top $25 \%$ (left upper panel) and the top $10 \%$ (right upper panel) as a criterion, and for GOM (left bottom panel) and for PBM (right bottom panel). For both GOM and PBM, the criterion of the top $25 \%$ concentration was used.

with $\mathrm{NO}_{2}$ concentrations (Table 3), indicating that regional transport of TGM emitted from coal combustion was impacting the site throughout much of the sampling period. PBM concentrations also had a statistically significant relationship with TGM and CO suggesting regional transport is also important for PBM, but GOM was not correlated with any other pollutant suggesting it is impacted to a greater extent by local sources (see additional discussion below).

CPF plot shows that the top $25 \%$ TGM concentrations were associated with winds from the NNW and eastern direction, pointing towards northeastern China and inland Korean sources; however, when the criterion was set to the top $10 \%$ the winds from NNW became less important and the sources located in southern and eastern areas from the sampling site were identified as an important source direction (Fig. 5). The CPF plot for GOM is significantly different from the one for PBM. High PBM concentrations were associated with northern winds while GOM concentrations were enhanced during southeastern winds.

These results suggest that for PBM regional transport from Chinese and North Korea sources were more important than
Korean sources; in contrast coal-fired power plants located in the southern direction rather than regional transport impacted GOM concentration. It should be noted that this result is in apparent conflict with the finding that there was no relationship between GOM and $\mathrm{SO}_{2}$ concentrations. Total $\mathrm{SO}_{2}$ emissions from power plants in China $\left(18.6 \mathrm{Tg} \mathrm{yr}^{-1}\right)$ are much larger than in Korea $\left(0.09 \mathrm{Tg} \mathrm{yr}^{-1}\right)$, and $\mathrm{SO}_{2}$ emission rates per capita and per area in China also greatly surpass those in Korea (Lu et al., 2010). Much larger $\mathrm{SO}_{2}$ emissions in China raise the background $\mathrm{SO}_{2}$ concentration in the region and may mask any correlation between GOM and $\mathrm{SO}_{2}$ even if coal-fired power plants located in the southerly direction from the sampling site impacted GOM concentrations. In support of this hypothesis the pollution rose indicates that high $\mathrm{SO}_{2}$ concentrations are associated with westerly winds while high GOM concentrations are associated with southerly winds. It should be noted that only the top $25 \%$ of GOM and PBM concentrations were used as the criteria for the CPF plot because the number of samples for both species were significantly less than for TGM due to their longer sampling duration (12 h).

Among the eight sampling periods, the second period (April 2013) had the highest TGM, PBM and the second highest GOM average concentration, and $\mathrm{SO}_{2}, \mathrm{NO}_{2}, \mathrm{CO}$, and $\mathrm{PM}_{10}$ were also quite high (Table 1). During this period, TGM was statistically well correlated with $\mathrm{SO}_{2}(r=0.55)$, $\mathrm{NO}_{2}(r=0.56)$, and $\mathrm{CO}(r=0.36)$, with the highest Pearson correlation coefficient with $\mathrm{NO}_{2}$, the characteristic local pollutant. In addition, the CPF plot (for TGM) and the back trajectories were also associated with easterly winds transporting air masses from major Korean urban areas, supporting the previous suggestion that inland sources enhanced all three $\mathrm{Hg}$ concentrations during the second sampling period.

In contrast the fifth sampling period had the lowest GOM, PBM and the second lowest TGM concentrations (Table 1). Note however that the TGM concentrations for the first couple of days reached approximately $5 \mathrm{ng} \mathrm{m}^{-3}$ and gradually decreased to about $1 \mathrm{ng} \mathrm{m}^{-3}$ during the last days of sampling (Fig. 2), indicating that there was likely two different sources affecting $\mathrm{Hg}$ concentrations during this period. Back trajectories associated with high TGM concentrations passed through northeastern China, North Korea, and the industrial and/or metropolitan areas of Korea before arriving at the sampling site whereas trajectories during the low TGM concentrations spent long periods within the ocean boundary 
layer. Although $\mathrm{Hg}$ can be emitted from ocean surface (Han et al., 2007; UNEP, 2013) heavy rain and low solar radiation occurring during the last 2 days of this period probably inhibited emissions of $\mathrm{Hg}$ from the ocean surface.

\subsubsection{GOM / PBM ratio}

According to the CPF results, the winds from NW and NE of the sampling site were responsible for the elevated PBM concentrations while easterly winds pointing towards inland Korea were associated with increased GOM concentrations (Fig. 5). The finding that regional transport of TGM and PBM to the site is important is supported by their significant correlation with $\mathrm{CO}$ (Table 3). In order to identify the relative importance of local sources relative to regional transport, the ratio of GOM / PBM was used as an indicator because the atmospheric residence time of GOM is widely regarded to be shorter than that of PBM (even though there is no consensus on what specific chemical forms are collected by $\mathrm{KCl}$-coated denuders). The GOM / PBM ratio should be higher if local sources are more important, and the GOM/PBM ratio is likely to decrease as regional transport becomes more important. In this study the GOM / PBM ratios were categorized into three groups: low (0-2), middle (2-8), and high $(>8)$ and the frequency of wind direction was compared (Fig. 6). The result clearly indicates that the southerly and southeasterly winds were associated with high GOM / PBM ratios and that the westerly and northerly winds indicative of regional transport from China prevailed at lower GOM / PBM ratios. There was a weak negative correlation between the ratio of GOM / PBM and CO concentration at a significance level of 0.1 ( $p$ value $=0.089)($ Fig. S3), supporting the assertion that the GOM / PBM ratio decreased with the increased effect of regional transport. Lynam and Keeler (2005) also found that a high GOM / PBM ratio was observed with influences from local sources and low GOM / PBM ratios appeared with influence from regional sources in Detroit. In Korea, Kim et al. (2009) found a significant increase in the PBM/GOM ratio during high $\mathrm{PM}_{2.5}$ concentration events caused by regional transport from China.

The reciprocal of this ratio (i.e. GOM / PBM) was used to calculate $K_{\mathrm{p}}$ which indicates that the secondary formation of PBM through gas-particle partitioning became more important as the significance of regional transport increased, suggesting that secondary production was favored when air underwent regional transport, as has been shown previously (Lynam and Keeler, 2005). It should be noted that there are uncertainties related to different aerosol composition, particle surface area variations, and/or temperature change which can affect both $K_{\mathrm{p}}$ and the GOM / PBM ratio.

\subsubsection{PSCF results}

In order to locate potential source areas in more detail, PSCF was used. For TGM, potential sources were located in Liaon-

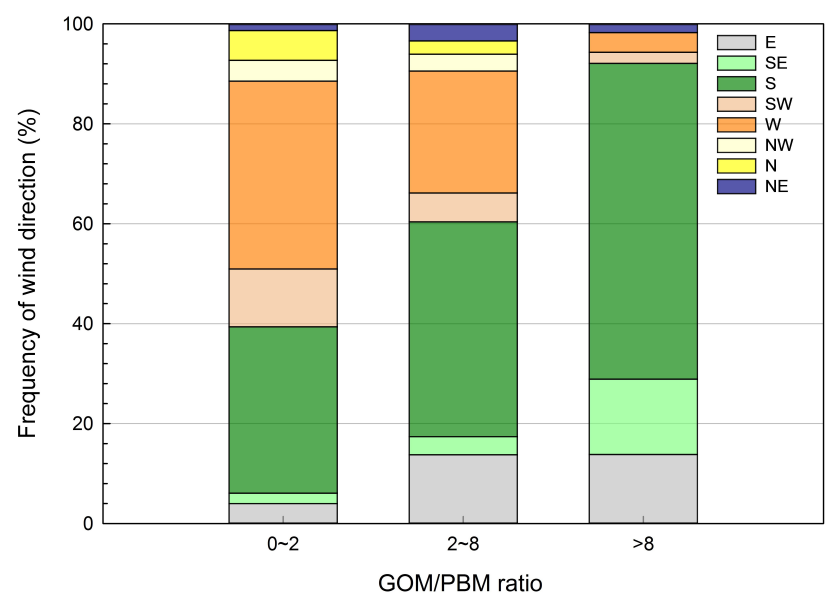

Figure 6. Frequency of wind direction with different GOM / PBM ratios. Southerly and easterly winds prevailed for the samples with high GOM / PBM ratio whereas the percentage of westerly winds increased as the GOM / PBM ratio decreased.

ing, Shandong, and Henan provinces of China along with the southern area of Korea (Fig. 7). Liaoning province, where large non-ferrous smelters are situated, is the province with the largest $\mathrm{Hg}$ emissions in China; Shandong and Henan provinces are also large $\mathrm{Hg}$ emission areas, emitting about 30-40 ton $\mathrm{yr}^{-1}$ (Fu et al., 2012) in part due to a large lead smelter (Wang et al., 2014) and biomass burning (Huang et al., 2011).

The probable source areas of PBM identified by PSCF were similar to those for TGM, indicating that both Chinese and inland Korean sources enhanced PBM concentrations, with the exception of metropolitan (Seoul) and industrial (Incheon) areas located in northwestern South Korea which emerged as more prominent source areas for PBM than for TGM (Fig. 7). Only Korean sources including metropolitan (Seoul) and the industrial areas in southern Korea were identified as probable source areas for GOM (Fig. 7); regional transport of GOM from China was not important. The Yellow Sea between China and Korea was also associated with high PSCF values, possibly indicating the shipping ports located on the western coast of Korea as important source areas. However, it should be noted that it might be a trailing effect derived by relatively short sampling duration. A trailing effect is often observed, especially with a limited number of measurements or short sampling period, since PSCF evenly distributes weight along the path of trajectories so that PSCF results often identify areas upwind and downwind of real sources as a source area (Han et al., 2007). However, it should be also noted that the marine boundary layer provides good conditions for active $\mathrm{Hg}$ oxidation reactions due to an abundance of oxidants (Auzmendi-Murua et al., 2014); therefore, the possibility of areas over the ocean being a GOM source should not be excluded. 


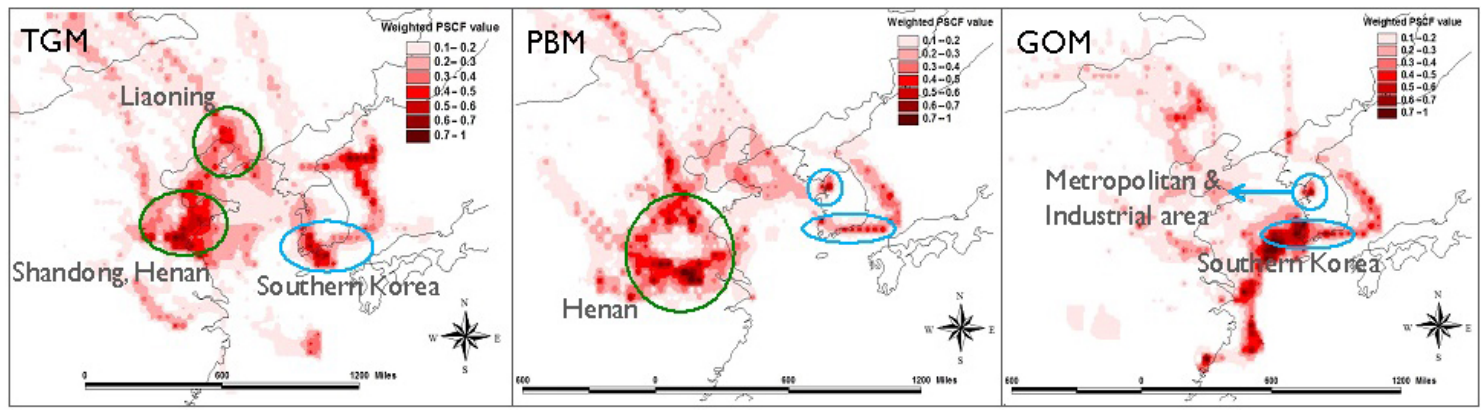

Figure 7. PSCF results for TGM (left), PBM (middle), and GOM (right) using the top $25 \%$ of concentrations as criteria.

Table 4. Estimated contribution of Korean and out-of-Korean sources on variations of speciated Hg concentration.

\begin{tabular}{|c|c|c|c|c|c|c|c|c|c|c|c|c|c|}
\hline \multirow[t]{2}{*}{ Cluster } & \multirow[t]{2}{*}{$\begin{array}{r}\text { Cluster } \\
\text { frequency }(\%)\end{array}$} & \multicolumn{3}{|c|}{ Average concentration* } & \multicolumn{3}{|c|}{ Source contribution $(\%)$} & \multicolumn{3}{|c|}{ Korean $(\%)$} & \multicolumn{3}{|c|}{ Out-of-Korean (\%) } \\
\hline & & TGM & GOM & PBM & TGM & GOM & PBM & TGM & GOM & PBM & TGM & GOM & PBM \\
\hline 1 & 12 & 2.2 & 6.9 & 7.7 & 9.6 & 10.5 & 8.6 & & & & 9.6 & 10.5 & 8.6 \\
\hline 2 & 31 & 2.8 & 8.3 & 12.6 & 31.5 & 32.5 & 36.5 & 15.7 & 16.3 & 18.2 & 15.7 & 16.3 & 18.2 \\
\hline 3 & 26 & 2.9 & 8.1 & 10.0 & 27.3 & 26.6 & 24.3 & 13.7 & 13.3 & 12.1 & 13.7 & 13.3 & 12.1 \\
\hline 4 & 20 & 2.6 & 9.0 & 12.3 & 18.9 & 22.8 & 23.0 & 18.9 & 22.8 & 23.0 & & & \\
\hline 5 & 11 & 3.2 & 5.5 & 7.4 & 12.8 & 7.6 & 7.6 & & & & 12.8 & 7.6 & 7.6 \\
\hline Korean & & & & & & & & 48.3 & 52.3 & 53.4 & & & \\
\hline Out-of-Korean & & & & & & & & & & & 51.7 & 47.7 & 46.6 \\
\hline
\end{tabular}

* TGM is shown in $\mathrm{ng} \mathrm{m}^{-3}$ while for both GOM and PBM the units are $\mathrm{pg} \mathrm{m}^{-3}$.

It should be noted that different temporal resolutions for trajectories (hourly) and concentrations (every $12 \mathrm{~h}$ ) were used for GOM and PBM. Since trajectory directions can significantly change over the course of $12 \mathrm{~h}$ there is a possibility that some source areas could be misidentified, especially for more distant regional sources. However, upon investigation it was determined that over the $12 \mathrm{~h}$ sampling periods the trajectories did not diverge significantly at this sampling site for most sampling periods.

\subsubsection{Source attribution based on cluster analysis}

In an effort to quantify the contribution of national and foreign sources to the measured $\mathrm{Hg}$ concentrations the back trajectories were grouped into five clusters using the trajectory cluster analysis feature of HYSPLIT. Among the five clusters, clusters 1 and 5 represent trajectories originating from outside (South) Korea whereas the trajectories grouped in the cluster 4 originated and passed through the (South) Korean peninsula (Fig. 8). Clusters 2 and 3 contain trajectories from China and the Korean peninsula, but cluster 2 was more associated with Liaoning province and North Korea while cluster 3 originated more from Shandong and Henan provinces. Clusters 1 through 5 contributed 12,31,26, 20, and $11 \%$ of the total time, respectively, and the associated concentrations with each cluster are shown in Table 4. Concentration ranges of three $\mathrm{Hg}$ species for each cluster were shown as the boxand-whisker plots in the Supplement (Fig. S5). When con- sidering that cluster 4 is associated with the local transport from inland Korea and cluster 1 and 5 are associated with the regional transport from outside of (South) Korea, the maximum and 75th percentile values as well as the arithmetic average are higher in cluster 4 for GOM and PBM than those in clusters 1 and 5 (Fig. S5).

The TGM concentration was the highest for cluster 5; however, GOM and PBM concentrations had the lowest averages for this cluster. Cluster 5 contains the back trajectories originating from Mongolia and Russia and passing through northeastern China before arriving at the sampling site, which suggests regional transport was important for this cluster (Fig. 8). Average $\mathrm{CO}$ concentrations were pretty similar for all clusters, but it was the second highest for cluster 5 (cluster 2 was highest). The highest total average GOM and PBM concentrations were associated with cluster 4 which includes trajectories distributed over the Korean peninsula, suggesting that Korean sources were responsible for the enhanced GOM and PBM concentrations. For cluster 4 , the highest Pearson correlation coefficient between GOM and PBM concentrations $(r=0.721)$ was observed, indicating that both $\mathrm{Hg}$ species were emitted from similar sources. For other clusters, there were no statistically significant correlations between GOM and PBM except for cluster $2(r=0.209, p$ value $<0.001)$. In addition, both average $\mathrm{NO}_{2}$ concentration $(19.4 \pm 14.9 \mathrm{ppb})$ and the correlation coefficient between $\mathrm{NO}_{2}$ and TGM $(r=0.688)$ were the high- 


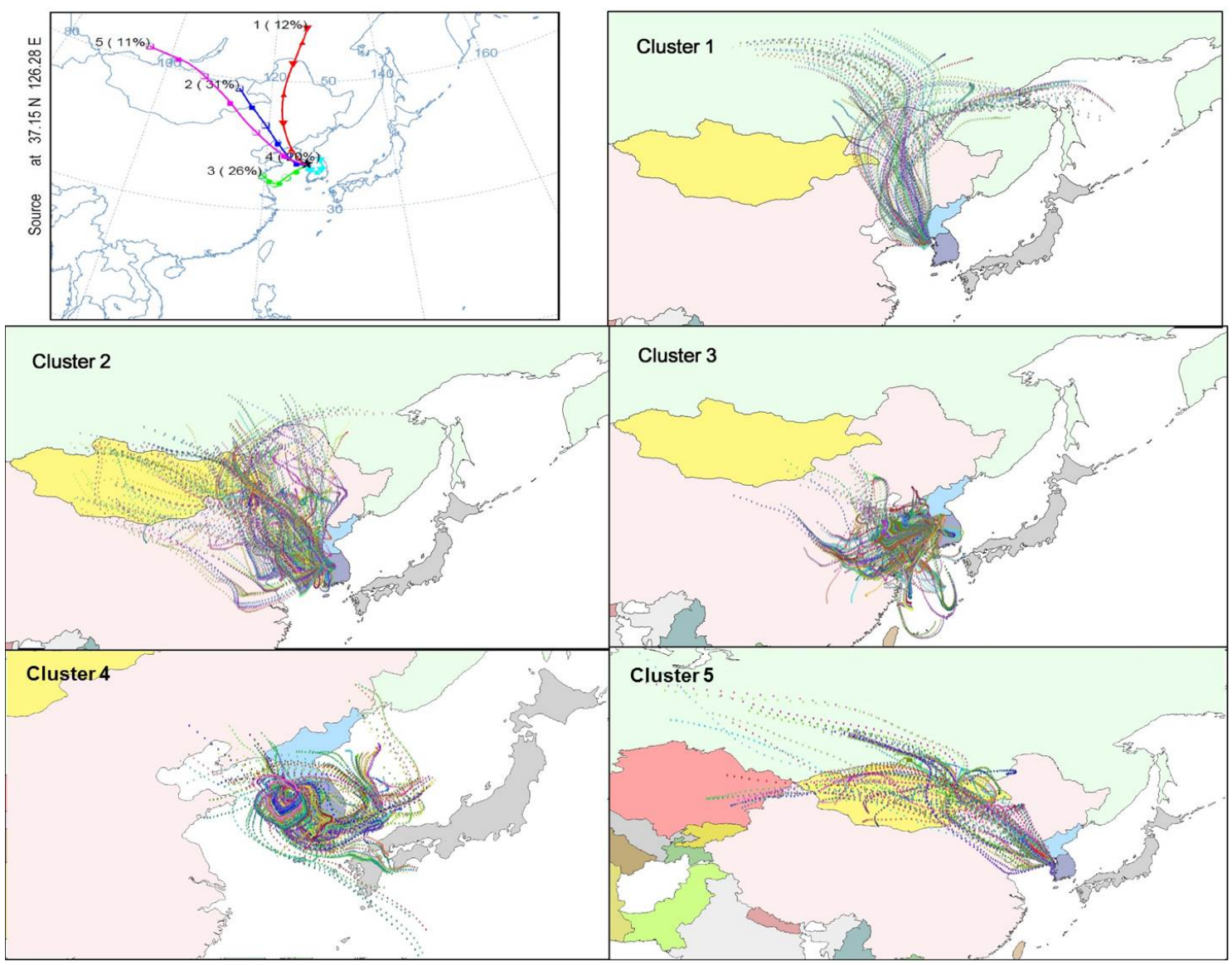

Figure 8. Back trajectories for clusters 1 through 5. The left top panel indicates the mean back trajectory and contribution for each cluster.

est for cluster 4, supporting the finding of impact from Korean sources.

In order to consider both $\mathrm{Hg}$ concentration and the fraction of time for each cluster, the following equation was used to quantify the effect of Korean and out-of-Korean sources to the $\mathrm{Hg}$ concentration at the receptor site.

source contribution of cluster, $i$

$$
=\frac{\left(\frac{N_{i}}{N_{\text {total }}}\right) \times C_{j}}{\sum_{i=1}^{n}\left\{\left(\frac{N_{i}}{N_{\text {total }}}\right) \times C_{j}\right\}},
$$

where $\left(N_{i} / N_{\text {total }}\right)$ indicates the percentage of time associated with the cluster, $i, i$ is the cluster number, $n$ is the number of clusters (equal to five in this study), and $C_{j}$ indicates the average $\mathrm{Hg}$ concentration associated with the cluster, $i$. Compared to the other clusters, the source contributions of clusters 1 and 5, which represent regional transport, were relatively low for all $\mathrm{Hg}$ species (Table 4). Cluster 4 contributed more significantly, especially for GOM and PBM, indicating the importance of Korean sources. The source contribution of cluster 2 was the highest for PBM compared to other $\mathrm{Hg}$ species, suggesting that North Korean sources were an important contributor to the high PBM concentrations measured, likely due to coal and biomass burning in North Korea (Kim et al., 2013; NI, 2001, 2003).

In order to quantify the contribution of Korean vs. out-ofKorean sources (note that "Korean" means "South Korean" throughout the manuscript), the source contributions of the clusters were used. Clusters 1 and 5 were used to represent the effect of sources outside of Korea and cluster 4 was used to indicate the effect of sources in Korea. Since clusters 2 and 3 contain mixed trajectories from Korea and out-of-Korea their contribution was divided evenly between in and out of Korea. The results indicate that the sources in Korea and outside Korea contributed about $50 \%$ each to the concentration variation of TGM measured at the sample site during the sampling period while the Korean sources affected GOM and PBM more significantly, accounting for approximately 52.3 and $53.4 \%$, respectively (Table 4). These results augment the CPF and PSCF results which only use concentrations that are in the top 25th percentile. While CPF and PSCF found that for high concentration events Korean sources were most important for GOM while for TGM and PBM regional transport from China and North Korea were also important, the clusterbased approach suggests that for all three species Korean and 
out-of-Korean sources contributed approximately $50 \%$ each to the concentration variations seen by the site. When the geometric mean concentrations were used for each cluster a similar result was obtained for relative contributions as the results using arithmetic mean concentrations.

It should be noted that errors always exist in calculating trajectories, causing uncertainties in all trajectory-based approaches. Trajectory errors vary considerably from case to case; Stohl (1998) suggested uncertainties might be $20 \%$ of the distance traveled by trajectories while Draxler (1996) found that the final error was about $10 \%$ of the travel distance.

\section{Conclusion and implications}

This study was initiated to identify the sources affecting speciated mercury concentrations measured on an island located between mainland Korea and Eastern China. Various tools were used to locate and quantify the sources, including correlations with other pollutants, CPF, and the back-trajectorybased analysis (PSCF and cluster analysis). The results consistently show that Korean sources are most important for GOM while for other $\mathrm{Hg}$ species (TGM and PBM) regional transport from China and North Korea were also important. Existing methods including PSCF and CPF are able to locate the source direction and areas, but do not consider the frequency of the wind directions which can affect the longterm concentrations at the receptor site. For example, if the $\mathrm{Hg}$ concentration is high with easterly winds both $\mathrm{CPF}$ and PSCF identify the eastern areas as important source areas even if, in fact, winds are rarely blowing from the east. In this work, it is true that sources located in the eastern direction from the sampling site are likely to be important for enhancing $\mathrm{Hg}$ concentrations, but based only on CPF and PSCF results it cannot be said that their contribution to the concentration variations at the site is also high.

To address this problem a new approach that considers both the cluster frequency and the $\mathrm{Hg}$ concentration associated with each cluster was used to quantify the source contribution at the sampling site. On average, contributions from out-of-Korean sources were similar to Korean sources for TGM whereas Korean sources contributed slightly more to the concentration variations of GOM and PBM compared to the out-of-Korean sources. However, in general, conclusions using this approach are more uncertain when the concentration ranges are similar between clusters. Additional work is needed with this approach to determine if a different statistic (other than mean) would provide better results when there are no distinct concentration differences between clusters. In addition, uncertainties exist in the source attribution approach based on cluster analysis because the trajectories inevitably overlap between different clusters since the cluster analysis accounts for both variations in transport speed and direction simultaneously. Nevertheless, this new approach can augment existing methods including CPF and PSCF to help identify source contributions to the concentration variations at the sampling site.

The ratio of GOM / PBM proved to be a useful tool for identifying the relative significance of local sources vs. regional transport. The GOM / PBM ratio decreased as the effect of regional transport increased and vice versa since GOM has a shorter atmospheric residence time than PBM. The $K_{\mathrm{p}}$ calculated using the reciprocal of the GOM / PBM ratio was negatively correlated with atmospheric temperature and positively correlated with relative humidity, suggesting that the secondary formation of PBM was an important source of atmospheric PBM concentration at low temperature and high relative humidity. This result also suggests that the secondary formation of PBM becomes more favored when the air undergoes regional transport rather than local transport.

\section{The Supplement related to this article is available online at doi:10.5194/acp-16-4119-2016-supplement.}

Author contributions. The work presented here was carried out in collaboration between all authors. Gang S. Lee analyzed data and wrote the paper. Pyung R. Kim performed the experiments and interpreted the results. Young J. Han defined the research theme, interpreted the results, and wrote the paper. Yong S. Seo, Seung. M. Yi, and Thomas M. Holsen also interpreted the results and approved the final paper.

Acknowledgements. This work was funded by the National Research Foundation of Korea (NRF) grant funded by the Korea government (MSIP) (No. 2015R1A2A2A03008301) and the Korea Ministry of Environment (MOE) as "the Environmental Health Action Program". This research was also supported by 2014 Research Grant from Kangwon National University (No. C1011758-01-01).

Edited by: L. Zhang

\section{References}

AMAP/UNEP: Technical Background Report on the Global Anthropogenic Mercury Assessment; Arctic Monitoring and Assessment Programme/UNEP Chemicals Branch, p. 159, 2013.

Amato, F. and Hopke, P. K.: Source apportionment of the ambient $\mathrm{PM}_{2.5}$ across St. Louis using constrained positive matrix factorization, Atmos. Environ., 46, 329-337, 2012.

Amos, H. M., Jacob, D. J., Holmes, C. D., Fisher, J. A., Wang, Q., Yantosca, R. M., Corbitt, E. S., Galarneau, E., Rutter, A. P., Gustin, M. S., Steffen, A., Schauer, J. J., Graydon, J. A., Louis, 
V. L. St., Talbot, R. W., Edgerton, E. S., Zhang, Y., and Sunderland, E. M.: Gas-particle partitioning of atmospheric $\mathrm{Hg}(\mathrm{II})$ and its effect on global mercury deposition, Atmos. Chem. Phys., 12, 591-603, doi:10.5194/acp-12-591-2012, 2012.

Ariya, P. A.: Atmospheric science: mid-latitude mercury loss, Nat. Geosci., 4, 14-15, 2011.

Auzmendi-Murua, I., Castillo, A., and Bozzelli J. W.: Mercury Oxidation via Chlorine, Bromine, and Iodine under atmospheric conditions: Thermochemistry and Kinetics, J. Phys. Chem., 118, 2959-2975, 2014.

Baya, A. P. and Van Heyst, B.: Assessing the trends and effects of environmental parameters on the behaviour of mercury in the lower atmosphere over cropped land over four seasons, Atmos. Chem. Phys., 10, 8617-8628, doi:10.5194/acp-10-86172010, 2010 .

Cheng, I., Zhang, L., Mao, H., Blanchard, P., Tordon, R., and John, D.: Seasonal and diurnal patterns of speciated atmospheric mercury at a coastal-rural and coastal-urban site, Atmos. Environ., 82, 193-205, 2014.

Cheng, L., Zhang, L., and Blanchard, P.: Regression modeling of gas-particle partitioning of atmospheric oxidized mercury from temperature data, J. Geophy. Res.-Atmos., 119, 11864-11876, 2014.

Choi, H. D., Holsen, T. M., and Hopke, P. K.: Atmospheric mercury in the Adirondacks: concentrations and sources, Environ. Sci. Technol., 42, 5644-5653, 2008.

Draxler, R. R.: Trajectory optimization for balloon flight planning, Weather Forecast., 11, 111-114, 1996.

Draxler, R. R., Stunder, B., Rolph, G., Stein, A., and Taylor, A.: HYSPLIT_4 User's Guide, Silver Spring, Maryland, USA: NOAA Air Resour. Lab., available at: http://www.arl.noaa.gov/ documents/reports/hysplit_user_guide.pdf (last access: 1 February 2015), 2014.

Driscoll, C. T., Han, Y. J., Chen, C. Y., Evers, D. C., Lambert, K. F., Holsen, T. M., Kamman, N. C., and Munson, R. K.: Mercury contamination in forest and freshwater ecosystems in the Northeastern United States, Bioscience, 57, 17-28, 2007.

Edgerton, E. S.: Field investigation of RGM and fine particulate $\mathrm{Hg}$ measurement bias using dual Tekran analyzers, ICMGP 2015, 19 June 2015, Jeju, Korea, 2015.

Fang, G. C., Zhang, L., and Huang, C. S.: Measurement of sizefractionated concentration and bulk dry deposition of atmospheric particulate bound mercury, Atmos. Environ., 61, 371$377,2012$.

Finley, B. D., Jaffe, D. A., Call, K., Lyman, S., Gustin, M. S., Peterson, C., Miller, M., and Lyman, T.: Development, testing, and deployment of an air sampling manifold for spiking elemental and oxidized mercury during the Reno atmospheric mercury intercomparison experiment (RAMIX), Environ. Sci. Technol., 47, 7277-7284, 2013.

Fu, X., Feng, X., Qiu, G., Shang, L., and Zhang, H.: Speciated atmospheric mercury and its potential source in Guiyang, China, Atmos. Environ., 45, 4205-4212, 2011.

Fu, X., Feng, X., Sommar, J., and Wang, S: A review of studies on atmospheric mercury in China, Sci. Total Environ., 421-422, 73-81, 2012.

Galindo, N., Yubero, E., Nicolás, J. F., Crespo, J., Pastor, C., Carratalá, A., and Santacatalina, M.: Water-soluble ions measured in fine particulate matter next to cement works, Atmos. Environ., 45, 2043-2049, 2011.

Gratz, L. E., Keeler, G. J., Marsik, F. J., Barres, J. A., and Dvonch, T.: Atmospheric transport of speciated mercury across southern Lake Michigan: Influence from emission sources in the Chicago/Gary urban area, Sci. Total Environ., 448, 84-95, 2013.

Gustin, M. S., Huang, J., Miller, M. B., Peterson, C., Jaffe, D. A., Ambrose, J., Finley, B. D., Lyman, S. N., Call, K., Talbot, R., Feddersen, D., Mao, H., and Lindberg, S. E.: Do we understand what the mercury speciation instruments are actually measuring? Results of RAMIX, Environ. Sci. Technol., 47, 7295-7306, 2013.

Gustin, M. S., Amos, H. M., Huang, J., Miller, M. B., and Heidecorn, K.: Measuring and modeling mercury in the atmosphere: a critical review, Atmos. Chem. Phys., 15, 5697-5713, doi:10.5194/acp-15-5697-2015, 2015.

Han, Y. J., Holsen, T. M., and Hopke, P. K.: Estimation of source location of total gaseous mercury measured in New York State using trajectory-based models, Atmos. Environ., 41, 6033-6047, 2007.

Han, Y. J., Kim, J. E., Kim, P. R., Kim, W. J., Yi, S. M., Seo, Y. S., and Kim, S. H.: General trends of Atmospheric mercury concentrations in urban and rural areas in Korea and characteristics of high-concentration events, Atmos. Environ., 94, 754-764, 2014.

Hedgecock, I. M. and Pirrone, N.: Chasing quicksilver: Modeling the atmospheric lifetime of $\mathrm{Hg}^{0}(\mathrm{~g})$ in the marine boundary layer at various latitudes, Environ. Sci. Technol., 38, 69-76, 2004.

Huang, J. and Gustin, M. S.: Evidence for a free troposphere source of mercury in wet deposition in the Western United States, Environ. Sci. Technol., 46, 6621-6629, 2012.

Huang, J., Choi, H. D., Hopke, P. K., and Holsen, T. M.: Ambient mercury sources in Rochester, NY : Results from principal components analysis (PCA) of mercury monitoring network data, Environ. Sci. Technol., 44, 8441-8445, 2010.

Huang, J., Miller, M. B., Weiss-Penzias, P., and Gustin, M. S.: Comparison of gaseous oxidized $\mathrm{Hg}$ measured by $\mathrm{KCl}$-coated denuders, and nylon and cation exchange membranes, Environ. Sci. Technol., 47, 7307-7316, 2013.

Huang, X., Li, M., Friedli, H. R., Song, Y., Chang, D., and Zhu, L.: Mercury Emissions from Biomass Burning in China, Environ, Sci. Technol., 45, 9442-9448, 2011.

Jaffe, D. A., Lyman, S., Amos, H. M., Gustin, M. S., Huang, J., Selin, N. E., Levin, L., Sschure, A. T., Mason, R. P., Talbot, R., Rutter, A., Finley, B., Jaeglé, L., Shah, V., McClure, C., Ambrose, J., Gratz, L., Lindberg, S., Weiss-Penzias, P., Sheu, G. R., Fedddersen, D. D., Horvat, M., Dastoor, A., Hynes, A. J., Mao, H., Sonke, J. E., Slemr, F., Fisher, J. A., Ebinghaus, R., Zhang, Y., and Edwards, G.: Progress on understanding atmospheric mercury hampered by uncertain measurements, Environ. Sci. Technol., 48, 7204-7206, 2014.

Kelly, C., Toro, R., Di Martino, A., Cox, C. L., Bellec, P., Castellanos, F. X., and Milham, M. P.: A convergent functional architecture of the insula emerges across imaging modalities, Neuroimage, 61, 1129-1142, 2012.

Kim, I. S., Lee, J. Y., and Kim, Y. P.: Impact of polycyclic aromatic hydrocarbon (PAH) emissions from North Korea to the air quality in the Seoul Metropolitan Area, South Korea, Atmos. Environ., 70, 159-165, 2013. 
Kim, J. H., Park, J. M., Lee, S. B., Pudasainee, D., and Seo, Y. C.: Anthropogenic mercury emission inventory with emission factors and total emission in Korea, Atmos. Environ., 44, 27142721, 2010.

Kim, M., Deshpande, S. R., and Crist, K. C.: Source apportionment of fine particulate matter $\left(\mathrm{PM}_{2.5}\right)$ at a rural Ohio River Valley site, Atmos. Environ., 41, 9231-9243, 2007.

Kim, P. R., Han, Y. J., Holsen, T. M., and Yi, S. M.: Atmospheric particulate mercury: Concentrations and size distributions, Atmos. Environ., 61, 94-102, 2012.

Kim, S. H., Han, Y. J., Holsen, T. M., and Yi, S. M.: Characteristics of atmospheric speciated mercury concentrtions (TGM, $\mathrm{Hg}$ (II), and $\mathrm{Hg}(\mathrm{p}))$ in Seoul, Korea, Atmos. Environ., 43, 3267-3274, 2009.

Lan, X., Talbot, R., Castro, M., Perry, K., and Luke, W.: Seasonal and diurnal variations of atmospheric mercury across the US determined from AMNet monitoring data, Atmos. Chem. Phys., 12, 10569-10582, doi:10.5194/acp-12-10569-2012, 2012.

Landis, M. S. and Keeler, G. J.: Atmospheric mercury deposition to Lake Michigan during the Lake Michigan mass balance study, Environ. Sci. Technol., 36, 4518-4524, 2002.

Lee, G. S., Kim, P. R., Han, Y. J., Holsen, T. M., and Lee, S. H.: Tracing sources of total gaseous mercury to $\mathrm{Y}$ ongheung Island off the coast of Korea, Atmosphere, 5, 273-291, 2014.

Lin, C. J. and Pehkonen, S. O.: The chemistry of atmospheric mercury: a review, Atmos. Environ., 33, 20674-2079, 1999.

Lynam, M. M. and Keeler, G. J.: Automated speciated mercury measurements in Michigan, Environ. Sci. Technol., 39, 92539562, 2005.

Lyman, S. N. and Gustin, M. S.: Determinants of atmospheric mercury concentrations in Reno, Nevada, USA, Sci. Total. Environ., 408, 431-438, 2009.

Lyman, S. N., Jaffe, D. A., and Gustin, M. S.: Release of mercury halides from $\mathrm{KCl}$ denuders in the presence of ozone, Atmos. Chem. Phys., 10, 8197-8204, doi:10.5194/acp-10-81972010, 2010.

Liu, B., Keeler, G. J., Timothy Dvonch, J., Barres, J. A., Lynam, M. M., Marsik, F. J., and Morgan, J. T.: Urban-rural differences in atmospheric mercury speciation, Atmos. Environ., 44, 20132023, 2010.

Lu, W., Zhu, Z. Y., and Liu, W. P.: Salt water intrusion numerical simulation on application based on FEFLOW, Ground Water, 32, 19-21, 2010.

Malcolm, E. G. and Keeler, G. J.: Evidence for a sampling artifact for particulate-phase mercury in the marine atmosphere, Atmos. Environ. 41, 3352-3359, 2007.

Mao, H., Talbot, R., Hegarty, J., and Koermer, J.: Speciated mercury at marine, coastal, and inland sites in New England - Part 2: Relationships with atmospheric physical parameters, Atmos. Chem. Phys., 12, 4181-4206, doi:10.5194/acp-12-4181-2012, 2012.

Mason, R. P. and Sullivan, K. A.: Mercury in Lake Michigan, Environ. Sci. Technol., 31, 942-947, 1997.

Mason, R. P., Morel, F. M. M., and Hemond, H. F.: The role of microorganisms in elemental mercury formation in natural water, Water Air Soil Poll., 80, 775-787, 1995.

McClure, C. D., Jaffe, D. A., and Edgerton, E. S.: Evaluation of the $\mathrm{KCl}$ denuder method for gaseous oxidized mercury using $\mathrm{HgBr}_{2}$ at an In-Service AMNet site, Environ. Sci. Technol., 48, 1143711444, 2014.
Mergler, D., Anderson, H. A., Chan, L. H. M., Mahaffey, K. R., Murray, M., and Sakamoto, M.: Methylmercury exposure and health effects in humans: a worldwide concern, Ambio, 36, 3$11,2007$.

NI (Nautilus Institute for Security and Sustainable Development): Rural energy survey in Unhari Village, the Democratic People's Republic of Korea (DPRK): Methods, results, and implications, Berkely, California, USA, 2001.

NI (Nautilus Institute for Security and Sustainable Development): The DPRK Energy Sector: Estimated Year 2000 Energy Balance and Suggested Approaches to Sectoral Redevelopment, Berkeley, California, USA, 2003.

Obrist, D., Johnson, D. W., Lindberg, S. E., Luo, Y., Hararuk, O., Bracho, R., Battles, J. J., Dail, D. B., Edmonds, R. L., Monson, R. K., Ollinger, S. V., Pallardy, S. G., Pregitzer, K. S., and Todd D. E.: Mercury Distribution Across 14 U.S. Forests. Part I: Spatial Patterns of Concentrations in Biomass, Litter, and Soils, Environ. Sci. Technol., 45, 3974-3981, 2011.

Pirrone, N., Keeler, G. J., and Nriagu, J. O.: Regional differences in worldwide emissions of mercury to the atmosphere, Atmos. Environ., 30, 2981-2987, 1996.

Pirrone, N., Aas, W., Cinnirella, S., Ebinghaus, R., Hedgecock, I. M., Pacyna, J., Sprovieri, F. and Sunderland, E. M.: Toward the next generation of air quality monitoring: Mercury, Atmos. Environ., 80, 599-611, 2013.

Polissar, A. V., Hopke, P. K., and Harris, J. M.: Source regions for atmospheric aerosol measured at Barrow, Alaska, Environ. Sci. Technol., 35, 4214-4226, $2001 \mathrm{a}$.

Polissar, A. V., Hopke, P. K., and Poirot, R. L.: Atmospheric aerosol over Vermont: Chemical composition and sources, Environ. Sci. Technol., 35, 4604-4621, 2001b.

Rutter, A. P. and Schauer, J. J.: The effect of temperature on the gasparticle partitioning of reactive mercury in atmospheric aerosols, Atmos. Environ., 41, 8647-8657, 2007a.

Rutter, A. P. and Schauer, J. J.: The impact of aerosol composition on the particle to gas partitioning of reactive mercury, Environ. Sci. Technol., 41, 3934-3939, 2007b.

Seinfeld, J. H. and Pandis, S. N.: Atmospheric chemistry and physics: From air pollution to climate change, 2nd Edn., John Wiley \& Sons, Inc., Hoboken, New Jersey, USA, 2006.

Stohl, A.: Computation, accuracy and applications of trajectories A review and bibliography, Atmos. Environ., 32, 947-966, 1998.

Subir, M., Ariya, P. A., and Dastoor, A. P.: A review of uncertainties in atmospheric modeling of mercury chemistry I. Uncertainties in existing kinetic parameters - Fundamental limitations and the importance of heterogeneous chemistry, Atmos. Environ., 45, 5664-5676, 2011.

Subir, M., Ariya, P. A., and Dastoor, A. P.: A review of the sources of uncertainties in atmospheric mercury modeling II. Mercury surface and heterogeneous chemistry - A missing link, Atmos. Environ., 46, 1-10, 2012.

Talbot, R., Mao, H., Feddersen, D., Smith, M., Kim, S. Y., Sive, B., Haase, K., Ambrose, J., Zhou, Y., and Russo, R.: Comparison of particulate mercury measured with manual and automated methods, Atmosphere, 2, 1-20, 2011.

Temme, C., Einax, Jr., W., Ebinghaus, R., and Schroeder, W. H.: Measurements of atmospheric mercury species at a coastal site in the Antarctic and over the South Atlantic Ocean during polar summer, Environ. Sci. Technol., 37, 22-31, 2002. 
Timonen, H., Ambrose, J. L., and Jaffe, D. A.: Oxidation of elemental $\mathrm{Hg}$ in anthropogenic and marine airmasses, Atmos. Chem. Phys., 13, 2827-2836, doi:10.5194/acp-13-2827-2013, 2013.

UNEP: The Global Atmospheric Mercury Assessment, UNEP Chemicals Branch, Geneva, Switzerland, 2013.

US EPA: Mercury Study Report to Congress, Office of Air Quality Planning and Standards and Office of Research and Development, EPA-452/R-97-005, 1997.

Wan, Q., Feng, X. B., Julia, L., Zheng, W., Song, X. J., Han, S. J., and $\mathrm{Xu}, \mathrm{H} .:$ Atmospheric mercury in Changbai Mountain area, northeastern China - Part 1: The seasonal distribution pattern of total gaseous mercury and its potential sources, Environ. Res., 109, 201-206, 2009a.

Wan, Q., Feng, X. B., Julia, L., Zheng, W., Song, X. J., Han, S. J., and $\mathrm{Xu}, \mathrm{H} .:$ Atmospheric mercury in Changbai Mountain area, northeastern China II. The distribution of reactive gaseous mercury and particulate mercury and mercury deposition fluxes, Environ. Res., 109, 721-727, 2009 b.

Wang, L., Wang, S., Zhang, L., Wang, Y., Zhang, Y., Nielsen, C., McElroy, B. M., and Hao, J.: Source apportionment of atmospheric mercury pollution in China using the GEOS-Chem model, Environ. Poll., 190, 166-175, 2014.

Wang, S., Holsen, T. M., Huang, J., and Han, Y.-J.: Evaluation of various methods to measure particulate bound mercury and associated artifacts, Atmos. Chem. Phys. Discuss., 13, 8585-8614, doi:10.5194/acpd-13-8585-2013, 2013.

Weiss-Penzias, P., Jaffe, D. A., Mcclintick, A., Prestbo, E. M., and Landis, M. S.: Gaseous elemental mercury in the marine boundary layer: evidence for rapid removal in anthropogenic pollution, Environ. Sci. Technol., 37, 3755-3763, 2003.

Weiss-Penzias, P., Jaffe, D. A., Swartzendruber, P., Dennison, J. B., Chand, D., Hafner, W., and Prestbo, E.: Observations of Asian air pollution in the free troposphere at Mount Bachelor Observatory during the spring of 2004, J. Geophys. Res., 111, D10304, doi:10.1029/2005JD006522, 2006.
Weiss-Penzias, P., Gustine, M. S., and Lyman, S.: Observations of speciated atmospheric mercury at three sites in Nevada, USA: Evidence for a free tropospheric source of reactive gaseous mercury, J. Geophys. Res., 114, D14302, doi:10.1029/2008JD011607, 2009.

Xiu, G. L., Jin, Q. X., Zhang, D. N., Shi, S. Y., Huang, X. J., Zhang, W. Y., Bao, L., Gao, P. T., and Chen, B.: Characterization of sizefractionated Particulate Mercury in Shanghai Ambient Air, Atmos, Environ., 39, 419-427, 2005.

Xiu, G. L., Cai, J., Zhang, W. Y., Zhang, D. N., Bueler, A., Lee, S. C., Shen, Y., Xu, L. H., Huang, X. J., and Zhang, P.: Speciated Mercury In size Fractionated Particles in Shanghai Ambient Air, Atmos. Environ., 43, 3145-3154, 2009.

Xu, L. L., Chen, J. S., Yang, L. M., Niu, Z. C., Tong, L., Yin, L. Q., and Chen, Y. T.: Characteristics and sources of atmospheric mercury speciation in a coastal city, Xiamen, China, Chemosphere, 119, 530-539, 2015.

You, C. H., Kim, B. G., Jo, E. M., Kim, G. Y., Yu, B. C., Hong, M. G., Kim, D. S., and Hong, Y. S.: The relationship between the fish consumption and blood total/methyl-mercury concentration of coastal area in Korea, NeuroToxicology, 33, 676-682, 2012.

Zhang, H., Feng, X., Larseen, T., Qiu, G., and Vogt, R. D.: In inland China, rice, rather than fish, is the major pathway for methylmercury exposure, Environ. Health Persp., 118, 1183-1188, 2010.

Zhang, H., Fu, X. W., Lin, C.-J., Wang, X., and Feng, X. B.: Observation and analysis of speciated atmospheric mercury in ShangriLa, Tibetan Plateau, China, Atmos. Chem. Phys., 15, 653-665, doi:10.5194/acp-15-653-2015, 2015.

Zhang, L., Gong, S., Padro, J., and Barrie, L.: A size-segregated particle dry deposition scheme for and atmospheric aerosol module, Atmos. Environ., 35, 549-560, 2001. 